7 (2016)

DOI: $10.18276 /$ rk.2016.7-15

Lena Magnone

The University of Warsaw

\title{
The Dangerous Age: \\ Polish Reception of Karin Michaëlis's Feminist Bestseller
}

Feminist bestsellers emerged shortly after women started writing novels. Jane Eyre (1847) caused a prompt wave of imitators, a "Jane Eyre mania", as Elaine Showalter calls the mass phenomenon of Anglo-Saxon women writers reproducing the narrative structure proposed by Charlotte Brontë: the struggle for independence of a resolute, bright, but also impoverished and unattractive heroine (Showalter, 2010: 103). On both sides of the Atlantic, international success was achieved by Harriett Beecher Stowe's abolitionary Uncle Tom's cabin (1852). Polish novel, Eliza Orzeszkowa's Marta (1873), which openly advocated the emancipation of women, was quickly translated into 19 languages. However, it was Den farlige Alder (1910) by a Danish writer, Karin Michaëlis (1872-1950), that not only sold in an inconceivable number of copies, but also made its author into a star. Her career lasted almost 20 years, and ended as fast as it began. During the second half of the 20th century her works ceased to be reprinted, and today Michaëlis is remembered solely by scholars. The aim of the following article is not to reclaim a forsaken author. By presenting the fate of the novel and marking the most important stages of its reception in Poland, both after and before World War I, I propose to ponder over the mechanisms behind the making of bestsellers in certain historical contexts.

\section{A dangerous novel}

In her most famous work, the author used a frequent genre in her oeuvre, i.e. the epistolary novel, complemented by the excerpts from the heroine's diary, to portray a woman who just entered the "dangerous age". According to Michaëlis's diagnosis, in the decade between the age of 40 and 50 a woman becomes finally mature, 
self-conscious and ready for passionate love, but at the same time she turns sexually invisible. Her body distinctly begins to age and social norms require that she remains within the current frames, regardless of how unhappy she feels trapped in an early marriage, in her role of a housewife or a mother. The protagonist, 42-year old Elsie Lindtner, decides to leave her husband after 20 years of a seemingly happy marriage, renounces any financial claims, and isolates herself with two servants on a small island where she ordered her lover, architect Jörgen Malthe, to build her dream "white Villa", determined to live the rest of her life in loneliness. Struggling to find herself, she discovers the extent of her sexual frustration. In solitude, she realizes that Malthe was the love of her life, and decides to pursue this relationship. The attempt is unsuccessful; the man, discouraged by many years of her indifference, does not love her anymore. Left in despair, Elsie tries to reconcile with her ex-husband, but he is already with another, much younger, woman. Although Elsie feels utterly defeated, the ending of the novel indicates that she gains self-knowledge and courage; the decision to travel around the world could be a start to a completely new life.

In many interviews, Michaëlis claimed that her novel was a documentary, that it uncovered a shameful secret of the insanity experienced by women in their forties. The protagonist proposed by Michaëlis was indeed a novelty in women's literature at the turn of the 19th century. She was not a maiden, romantic heroine or a young bride, but a mature woman reaching menopause. Such characters were previously cast only in supporting roles, often of satirical nature, e.g. as mothers trying to marry their daughters well or as eccentric old maids. Elsie is not a mother (although she fantasizes that if Malte was ten years younger and she ten years older, she could adopt him ${ }^{1}$ ), and she resigns from the role of a wife; she has her own desires and is ready to start her proper life, for which her youth was nothing but a preparation.

The decision to give a voice to this kind of heroine was in itself extraordinary. Elsie, as the author of letters and diaries, remains the only narrator. It is therefore through her eyes that her peers, other women struggling with menopause, such as Magna Wellmann, who ignoring her good reputation pursues dangerous sexual adventures, or Lilli Rothe, a married woman platonically in love with another man, who pays an unfairly high price for this innocent affection, are presented. Pages devoted to those women, although by tint of them the novel is not only a description of one isolated case but of the female condition in general, are unrelenting. Elsie knows and understands the origins of their crises, but does not approve of their

1 It is a recurrent motif in Michaëlis's works, cf. Eyben, 2003. 
attempts at dealing with the new situation Her own choices seem to be an effort to avoid experiencing her inner conflict in the public eye, and are to a large extent driven by fear of public humiliation. It is a sort of a voluntary exile from the polis.

The explicit description of sexuality of a woman at the age perceived by then as the beginning of senility, caused a scandal, which resulted in an unprecedented commercial success. The novel was immediately translated into German by Mathilde Mann, who had already regularly introduced Michaëlis's works to her fellow countrywomen ${ }^{2}$. This edition (in a month sold in 60,000 copies, in half a year - in 100,000) served as the basis for subsequent translations. Overall, The Dangerous Age was released in 12 languages and sold in over a million copies. Many editions, including first the French publication and then the American one, were accompanied by an essay by Marcel Prévost, the famous author of Les demi-vierges (1894), who also decided to adapt the book to suit French tastes.

The popularity of the novel was aided by the author's decision to visit every larger European city and meet with potential readers to state her intentions in person and dismiss the accusations made by outraged critics ${ }^{3}$. In her own words, her purpose was not to provoke the public, but to bring to attention the undeserved suffering of women at the dangerous age, to caution men to be understanding, attentive and gentle, and by that preventing divorces and protecting the family institution.

Michaëlis had to persuade not only conservatives, but also suffragettes, who accused her of providing arguments against the emancipation of women through depicting them as ruled by laws of nature, irresponsible and unable to make decisions, and therefore unfit to make reasonable choice at the ballot box. They also criticized the medical approach to female sexuality and reinforcing antifeminist stereotypes. Indeed, Elsie does call herself hysterical on many occasions, and she does express views such as: "if men suspected what was going on in us women as

2 Mathilde Mann also translated Michaëlis's later works, and her German translations were used by other local translators instead of the Danish original (it was the case in Poland, which is visible in the translations of titles. They usually correspond to their German, and not Danish, equivalents, e.g. Lillemor, Ger. Das Schicksal der Ulla Fangel, Pol. Losy Ulli Fangel or Pigen, der smilede, Germ. Herr und Mädchen, Pol. Pan i dziewczyna). Mann's role in Michaëlis's international success warrants a separate study. Also, it seems not to be a coincidence that the only Michaëlis's biography in existence was written by an American Germanist; first published in German (Eddy, 2003), it was not translated to Danish until ten years later (Eddy, 2013).

3 For more information on lectures as one of the important media of modernity see Stewart, 2009. As the author demonstrates, despite the fact that for women attending such lectures was one of the few ways of engaging in the public life, they could rarely be conducted by women and even if it was the case, it was frowned-upon. 
soon as we reach our fortieth year, they would fly from us like from the pest or kill us like mad dogs". The novel prompted therefore some unlikely alliances. During Michaëlis's visit in Gdańsk, her lectures were condemned in notices in local papers, unanimously signed by The Danzig Organization for Women Suffrage, The Organization of Danzig Adult Education Teachers, the Danzig Organization for the Well-being of Women, the Gdańsk branch of the International Federation of Abolitionists, the Mercantile League for Women Employees, the German Evangelical Women's Club, and the Union for the Opposition to Trash and Smut in Word and Picture ${ }^{4}$.

The script to a feature film based on Michaëlis's novel was created as early as 1911. It was the first German full-length movie. The film was produced by a pioneer of cinematography Oskar Messter and directed by Adolf Gärtner (the same year a Danish adaptation was created, which was in fact a copy of the German film, directed by August Blom [Ligensa 215: 229-230]). In his autobiography, the producer admitted, that neither he, nor the screenwriter (!) had read the original, and that they just intended to exploit the title's popularity. It does explain a series of inconsistencies between the novel and the pseudo-adaptation, which focused on the sensational motifs. The film version of Elsie, characterized by sexual appetite and promiscuity of Magna Wellmann, seduces her daughter's fiancé (a distant echo of a story of a maid, who catches her mother cheating in the novel), and in the end is taken to a psychiatric hospital like Agatha Ussing. The characters are not from the middle class as in the original, but aristocrats; they are decadent and cultivate obsolete traditions (in this version Elsie's husband gets killed in a duel with her lover).

One of the most interesting traces of the novel's influence is Tatiana Rosenthal's Freudian reading of The Dangerous Age (Rosenthal, 1911) 5 . Born in Minsk, Rosenthal (1884-1921) was one of the first women psychoanalysts, a member of the Russian Social Democratic Labour, and through it also The Bund. It seems interesting in itself, that Michaëlis's novel was analyzed by one of the "new women", a suffragist and revolutionary, who wrote the article for the still predominantly male psychoanalytic community. Notwithstanding the recognition of her peers, who saw her work as shedding light on the cases of frustrated mature women, who often

\footnotetext{
4 Quoted after Eddy, 1992: 499.
}

5 It is worth to add that in time Michaëlis herself became interested in psychoanalysis; in 1935, for "Politiken", a Copenhagen periodical with which she frequently worked (e.g. she was sent as a correspondent to the USSR in 1934), she reviewed Maria Bonaparte's Edgar Poe im Lichte der Psychoanalyse (the review was reprinted in "Almanach der Psychoanalyse" in 1936). 
sought therapy ("Karin Michaëlis's "The Dangerous Age" in the Light of Psychoanalysis. T. Rosenthal" [abstract], 1917: 341), it is above all an interesting literary interpretation, one of the earliest psychoanalytic analyses of literature (Freud's first reflection on the matter, the article Creative Writers and Day-Dreaming, was published in 1908).

Rosenthal recognizes Elsie Lindtner as a female type strongly present in Michaëlis's works, representing the author herself. This hypothesis allows her to complete the self-analysis conducted by the heroine on the pages of the diary with informations from the other novels of the Danish author. Rosenthal finds portrayals of young girls particularly informative, as they can serve to reconstruct Elsie's youth. Indeed, a frequently recurring protagonist in Michaëlis's works is that of a kind, naive, honest, and often talented girl, with a close connection to her father and in conflict with the mother (or raised without her). The child's perspective, allowing the author to discuss sexuality in an unpretentious though veiled manner, was used in her early works, such as Lillemor or Barnet.

According to the psychoanalyst, Elsie's personality was based on her identification with the father. Her whole life was marked with a "money complex" derived from it; the fear of sharing the fate of a bankrupt caused her to sell herself to the highest bidder. She therefore entered into a marriage of convenience and rejected the impoverished architect, who was in love with her. The suppressed sexual needs manifested themselves only during the menopause, when it was too late to fulfill them, which in turn resulted in a nervous breakdown.

Rosenthal uses identification with the father also to explain Elsie's narcissism and homoerotic tendencies visible in her relationship with a maid, who becomes her closest companion. With subtlety, Rosenthal describes the full of sexual tension scene of hair-brushing, interprets Elsie's fantasies about showing herself naked to another woman and her decision to share the bathroom with her maid. For Elsie Jeanne is a mirror, in which she sees a young and beautiful version of herself, while the history of the girl's erotic life (she also sold herself, but overtly, as a prostitute) allows Elsie to catch a glimpse of an alternative version of her own fate. This is the reason why the two women have to embark on the journey around the world together.

It is clear to the analyst that Elsie's condition is the result of her personal history, so that it is neither necessarily connected with physiological changes caused by menopause nor typical for women in general, although at the same time not unusual. If Elsie does not develop a mental illness as her peers, it is because of the fact that she released overwhelming emotions through self-analysis; keeping a diary serves 
the same purpose as the process of psychoanalysis. Rosenthal also draws attention to the fact that at one point Elsie notes down the idea to write a series of lectures on "the woman and the dangerous age", which is precisely what Michaëlis did. The author's European tournée can also be likened to a journey around the world, which her character begins at the end of the novel.

In 1911, the success of the novel was so great, that according to the editors of the "New York Times" the answer to "But who is Karin Michaëlis?" was: "simply the most talked about personality in Europe" ("All heroines not youthful. Karin Michaëlis, the Literary Sensation of Europe". New York Times July 30, 1911). From that point onwards, the author became a specialist in womanhood, unhappy marriage and divorce, touring the world with lectures for which the tickets were sold on the spot. Aside from being undoubtedly the most recognized name of the Danish literary scene, she was probably the most popular and read European woman writer. She also influenced the debutants of the day; among others, Colette stated that without inspiration from Michaëlis, her own works would have never come into existence (Lassner, 1991:11).

The "Michaëlis mania" reached Poland as well. Naturally, inhabitants of the former Polish territory annexed by Prussia and Austria were able to read the German edition of the bestseller. In the territory annexed by Russia, access to the novel was immediately provided by Warsaw-based "Nowa Gazeta". Already in issue 11 from 7 January 1911 the periodical edited by Stanisław Kempner reported the novel's publication, comparing the type of a 40-year old woman Michaëlis depicted to Balzac's "woman of thirty" ("Literatura i sztuka u obcych. Nowości literackie". Nowa Gazeta 11 [1911]: 7). The first part of The Dangerous Age was published in issue 44 from 27 January (the afternoon release). Because of the publication, the editors decided even to postpone the printing of another work. It simply could not wait. Introducing the bestseller to the Polish readers was of vital importance; so much so that the periodical disregarded publishing and press customs and bore additional costs (it informed its readers that "the subscribers that will join from 1 February will receive the beginning of the novel free of charge"; "Wiek niebezpieczny", 1911: 4). It seems that this was done with discreet hope of gaining more customers. Rival newspapers suggested that the publication of the sensational novel was prompted by the periodical's financial problems: "Nowa Gazeta" was supposedly losing subscribers, and tried everything to avoid going out of business ("Echa Prawdy". Prawda 13 (1911): 8). The novel was issued irregularly and in very short parts, which proves that the anonymous translation was prepared almost simultaneously. 
As many as three book editions of the novel appeared the same year, in three different translations (also different from the press edition). This threefold invasion could be explained by the fact that each of the three partitions had an autonomous publishing market, while the flow of people and things was restricted and subjected to rigorous control. The law of the Austrian partition was the most liberal; e.g. there was no preventive censorship, and therefore forbidden books were published in Lviv or Cracow and illegally or semi-legally transported to the Russian partition. It was, however, not the case with The Dangerous Age. Michaëlis's novel was published by "Kultura i Sztuka" in Lviv (as Niebezpieczny wiek. Pamiętnik i listy), by the Warsaw-based firm "Ultima Thule" (Wiek niebezpieczny) and by Gebethner and Wolff's publishing house, based in Warsaw, but also present in the Austrian partition, which released the book under the title Niebezpieczny wiek kobiety. It seems that it was a matter of competition between the publishers, who wanted to profit from the novel.

Besides the titles there are other differences between the editions, partly deriving from the marketing strategies. On the title page, "Kultura i Sztuka" informed that Kazimierz Króliński (actually Jan Denys, a teacher and poet from Lviv) translated from the Danish original. The other two editions lacked this note, therefore it can be assumed that they were translated from German. "Gebethner and Wolff" emphasized that Aleksandra Callier (known at the time mainly as the author of Higiena piękności: praktyczny poradnik dla prawdziwie eleganckich kobiet [Beauty hygiene. Practical guide for truly elegant women], first published in $1903^{6}$ ) translated the novel "with the author's permission", while the "Ultima Thule" edition included not only Michaëlis's portrait and a reproduction of her signature, but also an extensive note: "translated and supplemented with the author's lecture entitled Kobieta i wiek niebezpieczny, read in Berlin, Vienna and other European cities, and a commentary, by Alfred St. Iwieński”. Hidden behind the pseudonym was Stanisław Franciszek Michalski, the owner of a publishing house established just a year before, known primarily as a translator and promoter of the archaic Indian literature (Spychalska-Wilczurowa, 1962). The supplementation of the novel with the author's talk seems to be aimed at making the provincial Polish reader feel like a citizen of one of the European metropoles ${ }^{7}$, while the facsimile met the needs

6 In obituaries published after her death, the translation of The Dangerous Age was mentioned as her greatest accomplishment, see e.g. ([Obituary...]1923: 3).

7 Polish press published the accounts of Michaëlis's international lectures, e.g. the Cracow-based "Nowa Reforma" on 17 January 1911 reported her talk in Vienna. The short note ended with the 
of autograph hunters (the collectable character of the edition was emphasized by the fact that 10 copies were issued printed on handmade paper; anyhow "Ultima Thule" was known to specialize in bibliophilic editions; Sowiński, 2003: 91-107). It is worth pointing out that many years later, after Poland gained independence as a result of World War I, Michälis included new country in her international tournée and in 1927 visited Warsaw, which at the time developed from a city at the outskirts of the Russian Empire into a fully-fledged European capital. Until then, the Polish readers could read the talk the author gave in Vienna on 14 January 1911, where Michaëlis complained about the hostile reception of the novel in her homeland, and explained: "I wrote it because I had to, or rather I wanted a book like that to be written" (Michaëlis, 1911c: 166-167).

Only one of the editions, the one published in Lviv, was accompanied by advertisements of other works printed by the publishing house. "Kultura i Sztuka" decided on a very interesting choice of publicities, indirectly alluding to Michaëlis's target audience. Among the books recommended to the Galician readers was Leopold von Sacher-Masoch's famous Venus in Furs (published as Wenus w gronostajach), advertized in the following words: "Sacher-Masoch is the enemy of women who are... beautiful. His works are dominated by the view that a beautiful woman has all the potential for wild despotism, which she practices on a man if he is not capable of ruthlessly ruling over her. Venus in Furs is precisely such woman. The novel tells the story of a man who, as a slave, falls into her beautiful, strong hands". The same publishing house also issued two volumes of Sacher-Masoch's complete short stories. The first volume included those devoted to "the cruelty inflicted by women on men", while the other consisted of works in which "the author depicted women's heroism in love, their iron will and merciless revenge on their enemies". Another book was also advertised, The Heptameron of Margaret, Queen of Navarre, based on Boccacio's Decameron and written in the middle of the 16th century, which according to the editor was about "love, and love by no means hidden behind unnecessary covers, so much so that some prudes may view it as unsuitable for young ladies". On subsequent pages, there appeared ads encouraging the purchase of works such as the spiritualistic manual Potega spirytyzmu. Podręcznik do nadań nieznanych sfer życia duszy ze wskazówkami co do wywotywania zjawisk spirytystycznych or Yoga. Tajemna wiedza Indii.

statement "Mrs. Michaëlis's reflections, being both the advertisement and a defense of her novel, were captivating, and all the more feminine and incredible" ("Niebezpieczny wiek u kobiet". Nowa Reforma 26 [1911]: 2). 
The choice of advertisements may suggest that the publisher expected The Dangerous Age to be bought not by women (and if it was, it would be the particularly emancipated and immodest ones, and certainly not "young ladies"), but mainly men, searching for erotic themes and eager to discover the spicy secrets of femininity. The decision to set Michaëlis's novel beside Venus in Furs points to the fact that the editor viewed it as an equal literary scandal, a sensational and controversial work, which due to its questionable reputation could interest the readers and bring considerable profit. Moreover, the context of the esoteric works suggests that the publishing house aimed its marketing at a particular, rather common clientele.

It is important to add that Michaëlis, who published regularly since 1895, was not unknown in Poland. In 1905 an extensive outline of her work was wrote for the weekly periodical "Prawda" by Józefa Klemensiewiczowa, a renowned translator of Danish, Swedish, Norwegian and Finnish literature, a propagator of Scandinavian authors and the compiler of the first synthetic work on the topic, Literatura Skandynawii (1914). Distancing herself from the writer's obsessive fans, she credited her with a considerable, albeit still developing, talent. She praised Michaëlis's gift for observation, her ability to concisely formulate her thoughts, and the "dedication, with which she treats her work", but criticized her vivid imagination, which inspired "images, that make one's hair stand on end". Klemensiewiczowa claimed that in her first two works Michaëlis tried to write in a way that would make no-one suspect that she was a woman. Fortunately, later the "author's pride in that she is devoid of womanly gentleness, which would make her omit one real, but unseemly or outright vile, detail", seems to become a thing of the past: "currently published works prove that her talent has matured, harmonized and run a course more in agreement with her character" (Klemensiewiczowa, 1905: 213-214).

Klemensiewiczowa was particularly fond of the short story En lille Sjael, which she translated and published therein under the title Duszyczka (Michaëlis, 1907). She also appreciated the novels Lillemor (1902), Barnet (1902), Sönen (1903) i Gyda (1904). Klemensiewiczowa's appraisal most probably influenced the choice of the first Polish translation of the Danish author to be created, the novel Lillemor. The tragic story of 16-year old girl married to a 48-year old widower told in letters to her little sisters was published in two editions in one year: under the title W stepie as a suplement for the subscibers of the periodical "Bluszcz" (Michaëlis, 1904), and separately as Losy Ulli Fangel (Michaelis, 1905). In 1911 the Polish reader could also reach for Beata Rosa (1908). Both works touched upon matters that were still taboo at the time. Ulla Fangel experienced the trauma of the so-called marital cohabitation, her subsequent pregnancies ended in stillbirth, and ultimately she 
committed suicide. Beata Rosa was a daughter of a prostitute, and a murderer; she killed the rapist whose child she gave birth to after marrying another man, a vicar with very high moral standards. Michaëlis's passion for exposing such matters must have been associated by the Polish readers with the naturalistic works of Gabriela Zapolska, who was equally determined to bring to light the hypocrisy of the middle class, and raising subjects connected with double sexual morality, likewise accused of spreading pornography by conservative press (Kłosińska, 1999: 7-37).

The publication of The Dangerous Age was not, however, treated as a literary event, but as a social one. The reviews were not written by literary critics, but by specialists in women's matters of various sorts, like, e.g. a gynecologist, dr Ignacy Mucha, who wrote with blasé characteristic of a professional, that the facts described by the author were known for a long time by persons familiar with female physiology and aware of the extent of sexual frustration in mismatched marriages. Michaëlis's only contribution was presenting this knowledge in an accessible form of a novel. Although in the physician's opinion the novel was artistically meager, he credited the author for opposing the hypocrisy and "telling the honest truth" (Mucha, 1911: 7-8)

The translator's commentary added to the "Ultima Thule" edition is symptomatic for the way in which Michaëlis's novel was received in 1911. It is also a perfect example of the misogyny of the early modern period, and reflects the influence of Otto Weininger's famous book Sex and Character (1903), incidentally translated into Polish that same year.

In his initial words Iwieński already claims that "a creation of a woman's pen should not be considered a work of art. Women's art is of any value only if it permeates the secrets of the female soul; the secrets of female sexual instincts. If a woman wanted to or was capable of fulfilling this task, her role in literature would be different. Her work would cease to be what it is now, which is - absolutely nothing". According to the translator, the fair sex "is almost never aware of what is happening inside her, nor is she conscious of her instincts, like an insect or a bird". The influence of Michaëlis's novel derives from the fact that it is the first account exposing the female nature written by a woman. The translator states that the book does not in fact present the psychology of a period in a woman's life - "A woman's dangerous age does not last from the age of 40 to the age of 50. A woman is «dangerous» throughout her mature life, that is roughly from the age

8 According to Beverly D. Eddy it were the gynecologists who appreciated her work the most, and readily adopted the term "dangerous age" to describe menopause (Eddy, 1992: 501). The term was in fact used also by Simone de Beauvoir in Le Deuxième Sexe (1949). 
of 15 until the age of 50. She is «dangerous» throughout this long period, when she is fertile and her body bursts with a red flame every month. During this period, instinct dominates her whole being, and makes her unable to compete with male thought or male work".

In Iwieński's opinion, the author also captured one key feature of the fair sex hypocrisy, which is remnant of the prehistoric times, when she "had to use tricks and cunning to secure her peace and preserve the life of her unborn child - the future of the species" (Iwański's anthropological fantasy even claims that "the human female imitated the male and started to walk on two legs, while she should have stayed on all fours"). According to the translator, Elsie, who lies to everyone including herself, does not differ from other women. "She is an ordinary woman" - he emphasizes. At the same time, he compares Michaëlis's character with the protagonist of Ibsen's A Doll's House, however it is not, as it would seem, because of their perseverance and the courage to change the life they do not want after realizing that, in Elsie's words, they "sail under false colors". Iwieński argumentation goes along other lines: "The force which caused her and Nora to leave their hearth is the force that drives birds to fly South. It is inherent to any life form, controlling a butterfly as well as well as an elephant. Only in humans is it partially overcome by action, reason and man's thought. However, the woman's soul consists mainly of instinct, and in this regard she occupies the same position as any other animal" (Iwieński, 1911: 177-182).

Iwieński would have probably appreciated the sequel to The dangerous age written the next year, Elsie Lindtner (1912), which described the continuation of the character's travel. During her stay in New York, Elsie adopts a homeless orphan, with whom she returns to Denmark, determined to dedicate the rest of her life to caring for him. The woman's sexual energy is channeled into motherhood: at the end of the adventurous journey, the one who challenged all conventionality finds herself in a traditional female role. The novel was not, however, successful in Poland and it was neither translated nor discussed.

\section{The literary travelling saleswoman}

Shortly after World War I Michaëlis became one of the most translated women authors in Poland. She was also undoubtedly one of the most prolific authors, writing two works almost every year. Polish translations of her books appeared with similar regularity. From the 1920s the following novels were published: Spowiedź kobiety (in two editions, first in 1922, the second in 1929), Matżeństwo (1923, second 
edition entitled Mąż $i$ żona in 1928), Pani Jonna (1927), Metta Trap (1927), Siedem sióstr (1928), Sznur peret (1928), Gunhild (1929), Pierwsza mitość Gunhildy (1930), Pan i dziewczyna (1931), Tajemnica (1932), Matżenstwo Justyny (1936), Serce mojej matki (1937). Some of the editions included the number of sold copies, which suggests that the novels reached 3 to 4 thousand readers.

Almost all of the books were published by the publishing association "Rój" established in 1924 by the journalist Melchior Wańkowicz, and quickly becoming one of the biggest publishing houses in Poland at the time, specializing in fiction and issuing 30 new items a month. It was "Rój", that not only published the most prominent works of Polish authors (among others Bruno Schulz and Witold Gombrowicz), but also brought the Polish readers closer to contemporary international prose. The translators working for "Rój”, as well as for other big publishing houses, were mostly women (in the case of Michaëlis's works it were Maria Kreczkowska, whose actual surname was Feldmanowa, Bronisława Neufeldówna and, most importantly, Aniela Waldenbergowa). The work that resulted, as one of present-day researchers notes, was more frequently that with male translators a "functional object, a book treated more as the source of knowledge and entertainment that a work of art, because it introduced into the Polish language the «lacking» genres: crime, adventure, sensational, travel and romance novels, in other words well-written lower-category literature for adult and younger audiences" (Zawiszewska, 2014: 125). Michaëlis's prose could undoubtedly be included in this category.

The writer's popularity, in Poland as well as in Europe, peaked in 1927, when another film adaptation of The Dangerous Age was released. Das gefährliche Alter, directed by Eugen Illés, starring Asta Nielsen, a Danish actress who was one of the greatest stars of silent cinema, premiered on 17 November 1927. It could not be determined if the film appeared in Polish movie theatres 9 . It is, however, certain that Michaëlis, who started another promotional tour the year before, visited Poland. The tour included many German and Swiss cities, Austria, Yugoslavia and Romania. After approximately sixty talks, the author visited Cracow on 25 March, from where she traveled to Łodź on the next day, and to Warsaw the day after. In all of those places she gave speeches entitled Mitość - matżenstwo - rozwód [Love marriage - divorce], and in Warsaw she additionally organized a lecture only for women entitled Kobiety między sobą [Between women]. Press notes announced

9 The film is not mentioned in an extensive guide to the repertoire of Polish cinemas in the prewar period (Świdziński, 2015), however his author notes that a full account is not possible due to damages to materials during the war. 
her as "one of the most popular writers, and in fact the most popular woman in Europe” ("Karin Michaëlis w oświetleniu krakowskiego krytyka”, 1927: 2). Treated as a representative of some world empire, a diplomatic agent of the republic of women, she was invited to Belweder palace by the First Marshal of Poland, Józef Piłsudski. According to press accounts, the former scandalist presented a rather moderate program of reformation of the relations between sexes. She departed from her fame as a propagator of divorce, claiming that the institution of family could be improved by economic equality between the partners and teaching boys respect for women. Michaëlis mentioned that the wide-spread sexual initiation in brothels did not help the cause, however beside the idea of each mother making her sons swear to treat women as they would want others to treat her, she did not see a prospect for change in this matter. She also advocated, among other things, an insurance scheme for girls right after their birth in case of the father's or husband's death, and married women earning for their private expenses. With Marshal Piłudski she talked about children care, concerned with the well-being of underage newspaper sellers she noticed on the streets of Warsaw at night. During a dinner organized in her honor by the P.E.N. Klub in the Polonia Palace Hotel she expressed her dream of abolishing all borders and establishing better international understanding.

For the occasion, the weekly "Wiadomości Literackie", at the time the most popular and influential periodical about society and culture (Szpakowska, 2012), published on its first page an article by Zofia Nałkowska (Nałkowska, 1927: 1) ${ }^{10}$. The renowned writer, who debuted as a teenager at the time when Michaellis's first works were being published, and later became the central figure of interwar literary life, stylized the article as an account of the thoughts that accompanied her the morning she drove to greet the author on a Warsaw train station. Departing a little from the truth (which is evident from her Diaries ${ }^{11}$ ) she confessed that from the time of her youth Michaëlis was one of the women writers she most admired. Rather than a tribute to the author of The Dangerous Age, the article was a presentation of Nałkowska's genealogy as both a writer and emancipationist. This illuminating account suggests that aside from Polish women authors and pioneers of the campaign for women's rights, like Maria Wirtemberska, Klementyna Hoffmanowa or

10 The text was used also as the introduction to: Michaëlis, 1927a.

11 On 29 July 1910 after reading W stepie Nałkowska noted: "Skillfully written, but too trivial" (Nałkowska, 1976: 150). She decided to rediscover the author's works only during her second visit in Poland ("In recent times I owe much joy to Karin Michaëlis, whose books I reread with great appreciation"; Nałkowska, 1980: 237). 
Narcyza Żmichowska, Nałkowska also regarded as her "older sisters" the French authors: George Sand, Mademoiselle de Lespinasse, Madame de Stael, Ninon de Lenclos, and Madame de la Fayette. "How I loved them all, the writing women, those who carefully carried in outstretched hands their hearts, aflame with undying love", writes the author of Narcyza, and adds: "I do not know if it was really what I thought while I was going there. But it was all built up in me - and it caused seeing Karin Michaëlis to be an emotional experience of the same magnitude, encompassing admiration, tentative solidarity and a sort of love".

Despite this confession, a shadow of professional envy falls on Nałkowska's account when she describes Michaëlis's cosmopolitan life, frequent travels and visible signs of commercial success. She even wonders at one point if this life style - writing so many letters, giving numerous of lectures and constantly being interviewed - allows the writer to find the concentration needed for creative work. She decides that her rival's talent relates to her extraordinary emotional intelligence and the capacity for empathy. The types of women which the author portrays in her novels, so different from herself, are not the result of observation, but deep introspection: "it is through her heart, beating with joy and full of acceptance for life, that Karin Michaëlis learns the hearts of others. For women possess abilities which have to be developed in a dream, read as an unmistakable truth about oneself. Karin Michaëlis's women are dreams about her other selves". Nałkowska repeated this opinion in her Diaries, where she also expressed her disappointment with the fact that the author "does not compare to her books, in that she is too common, simple and plain" (Nałkowska, 1980: 237).

Disappointment is even more visible in the account of Aniela Kallas's (real name Korngutówna), a dramatist and a contributor to the Lviv-based periodical "Wiek Nowy”. The author of the first Polish translation of Michaëlis's book for children (Radosna szkota) gave her a copy as a gift. She describes with distaste, that instead of thanks she heard the question: "And where is the money for the copyrights?" (Kallas, 1927: 10). To Kallas, who declared (to both the writer and the readers), that she had not translated this book for profit but to introduce a valuable piece to Polish literature, it was unacceptable that Michaëlis treats her work just as any other profession. She mockingly compares her to a "literary saleswoman, travelling and presenting the samples of her talent from country to country". She seems to be particularly displeased with the fact that Michaëlis's strategy translates into profit ("I have the impression that Karin Michaëlis is probably the only writer to make so much profit with so little effort"). The translator was even bold enough to ask the writer if she is a Jew, and, with peculiar satisfaction, repeats her answer, that she 
would have nothing against being part of a nation which gave the world so many great people. She ends her account with information about a public disagreement Michaëlis had with a great Italian poet, D'Annunzio, who was going to move into a villa confiscated by the government, which was a property of a late Danish citizen. The writer spoke up for the wronged widow, which Kallas perceives as a calculated decision: "she wanted to regain the affection of the Danish people, defending the Dane and fighting in the name of justice. The controversy did Mrs. Todes no good. She lives in poverty, taken in by relatives from Denmark. However, Karin Michaëlis is discussed on both sides of the world" (Kallas, 1927: 11).

For Polish female writers the Dane's international success must have been vexing, because it clearly demonstrated what strategies a woman, writing in a local, not commonly known language of one of the smallest countries in Europe, has to adopt to achieve the popularity that seemed to be reserved to French and Anglo-Saxon authors. It is important to note that Michaëlis's success preceded the accomplishments of Scandinavian writers like Selma Lagerlöf and Sigrid Undset, that were willingly read and much appreciated in Poland. However, unlike the Swedish author, the first woman to receive the Nobel prize (1909), and the Norwegian, laureate of this award in 1928, Michaëlis was not considered an outstanding writer. Her success was based on the readability of her novels and the use of narrative structures taken from popular literature, which she skillfully complemented with comments on issues relevant at the time, connected with rapid social changes and vindications of the "new women".

Although it is difficult to discuss all of the press coverage, it is worthwhile to notice the manner in which Michaëlis's visit was commented by two most influential feminist periodicals, "Bluszcz" and "Kobieta Współczesna". "Bluszcz", established in 1865, was the oldest women's magazine in Poland; until the outbreak of World War II it was edited by Stefania Podhorska-Okołów. It had a conservative orientation, which is evident, e.g., in the belief in a woman's "natural" purpose, that is being a wife and a mother. Emancipation was supported by the weekly only to the extent in which it did not interrupt traditional female duties (Chwastyk-Kowalczyk, 2003). On the occasion of the writer's visit, the editors devoted almost the whole issue to her. It began with an interview conducted by the chief editor (Okołów-Podhorska, 1927: 1-2), followed by an article by Herminia Naglerowa, which reconstructed Michaëlis's program (Naglerowa, 1927: 2-3). In the chronicle, "Bluszcz" included a photograph from the dinner in her honor and an account of her lecture. The writer's worldview perfectly matched the periodicals agenda. It explains the lofty tone with which the editors announced that the author's talent "supported the 
efforts of the numerous activists who at the end of the previous century undertook the enormous struggle to eradicate the longtime prejudices".

The material published by "Kobieta Współczesna" are even more illuminating. It appeared in the second issue of the new periodical and can be treated as its manifesto. "Kobieta Współczesna" was in fact established in 1927 by the former contributors of "Bluszcz", lead by Emilia Grocholska and Wanda Pełczyńska. The weekly paper had a liberal orientation, promoted the absolute gender equality and encouraged women's active participation in public life. The reporter, Jadwiga Krawczyńska, viewed the stance of the Danish writer as "progressive, but moderate", and emphasized her "readiness for compromise in her need for reformation", and while writing about her feminism she put the word in quotation marks. The interview is essentially a series of well-aimed attacks. Krawczyńska begins by asking Michaëlis's opinion about the new generation of women, solely to expose the distance between the writer and the "postwar woman". In her answers, punctuated by aggressive questions, the Dane appears to be an opponent of engaging in sports, doubts the possibility of friendship between a woman and a man, and does not believe in achieving balance between work and family life. Even the description of the author's appearance serves to Krawczyńska as a way of distancing her: "[She has a] very ordinary physique. We all know the brave housewife, an older lady, stout and brisk. Everyone has at least one such aunt in the family". Even the "graying wavy hair style à la garçonne" does not help -it is only the final proof that Michaëlis is a newcomer from a previous era, and does not understand the needs of the "new women" or follow the fast-paced modern life (Krawczyńska, 1927: 14-15).

The writer returned to Warsaw in 1928, this time with lectures entiled Szczeście i nieszczęście w matżenstwie [Happiness and Unhappiness in Marriage] and Dzieci, rodzice a moralność [Children, parents and morality]. Soon after, in 1929, another edition of her most famous novel was published, Niebezpieczny wiek. Notatki $z$ pamiętnika $i$ listy. The translation, authorized by the author, was prepared by Bronisława Neufeldówna, a pioneer of women's professional life and one of the first Polish journalist, who from 1906 worked with "Nowa Gazeta”, where she ran an international column, a column entitled " $Z$ prowincji", and, with her sister Melania Łaganowska, a separate women's section. Although the translation of The Dangerous Age published in 1911 in "Nowa Gazeta" was anonymous, after collating it with the 1929 edition it becomes clear, that it was Neufeldówna who was the first to translate Michaëlis's novel.

The last pages of The Dangerous Age included a list of other works of the Dane accompanied by short recommendations. Metta Trap was provided with a note 
"Dubbed the "Danish Bachelor Girl" by Z. Rabska", and Pani Jonna with: "Called a «modern Madame Bovary» by Z. Nałkowska”.

In 1929 Michaëlis's novels were no longer juxtaposed with works the likes of Sacher-Masoch or Heptameron. Although the comparison with provocative bestsellers of male authors remained, the books were more relevant for the emancipationists of the time. The parallel of Pani Jonna (1907) to Madame Bovary comes from a preface to the Polish edition by Zofia Nałkowska. The masterpiece, which resulted in Flaubert facing a trial for obscenity in 1857, was an international success, imitated and paraphrased also in Poland, e.g. in Cham by Eliza Orzeszkowa (1888). Emma's personality had great influence on the women writers of the interwar period; it served as inspiration for the characters of Barbara in Noce $i$ dnie by Maria Dąbrowska, and Róża from the psychological novel Cudzoziemka by Maria Kuncewiczowa (Kaluta, 1995). Also in Michaëlis's works there are many characters depicting frustrated provincial women, dreaming of a passionate affair and paying the highest price for it, including of course the eponymous Jonna. In her novel, the Danish author proposed an interesting modification of Flaubert's plot. Beside Jonna, a mere by-stander to her life, she introduced two other characters, active, conquering and victorious women who were not ashamed of realizing their sexuality - Jonna's sister, Inga, who is known only as the recipient of the protagonist's letter, and Jonna's daughter, Maja, who would not hesitate to seduce a man her mother could only dream of.

The comparison of Metta Trap to The Bachelor Girl comes from an article by Zuzanna Rabska, a talented writer and journalist, who between 1925 and 1939 reviewed literary novelties for "Kurier Warszawski” (Zawiszewska, 2014: 449-478). Victor Margueritte's novel, which cause in France a moral scandal in 1922, was first translated into Polish by Leopold Staff in 1925 (into Yiddish by Pua Rakowska three years later), and to the outbreak of World War II was reprinted numerous times. The work established a new model of a female character, not bound by conventions and experimenting with her image and sexuality. Michaëlis's Metta Trap (1922; polish translation 1927) introduced an even bolder depiction of women; the protagonist is an ideal mother, but each of her well-raised daughters has a different father. Metta's choices resulted from observing the unhappy marriage of her parents. Having promised her dying mother to never marry, she wants to preserve her independence, both personal and economic. The advertisement for Metta Trap included in the edition of Pani Jonna resound: "It is a book read around the world, and it is moving for all women. The critics, due to its content and popularity, call it the Danish Bachelor Girl. However, whereas in The Bachelor Girl multitude of 
snobs are looking for a simple absolution, to Karin Michaëlis women pilgrimage seeking for answers to burning questions".

Similarly to Margueritte's novel, Metta Trapp was shortly published in Yiddish, just two years after the Polish edition, translated by Isaac Bashevis Singer himself. Also like The Bachelor Girl, the Dane's work was deemed "pornographic" and attacked by the Church and conservative press. In Przewodnik po beletrystyce, a guide to fiction published by the Chief Catholic Action Institute, Czesław Lechicki wrote about the author: "the outspoken advocate of the «idea" of bodily contact in general (...), tries to find the golden mean between motherhood and prostitution". Positive reactions came from left-wing and feminist circles; Metta Trap was given a very flattering review by Maria Dąbrowska in "Kobieta Współczesna” (Dąbrowska, 1927: 16). In "Wiadomości Literackie" Irena Krzywicka, generally rather hostile toward the writer, admitted, that as "Her Metta Trap (...) is an interesting illustration of Russell's predictions; it should be thought-provoking for any woman" (Krzywicka, 1931: 3). It seems that in the interwar period it was Metta Trap that was regarded as chef-d'evre of the Danish writer. In an article published in "Bluszcz", Zofia Miszewska without hesitation compared her novel to the works of Sigrid Undset (Miszewska, 1929: 6-7). Contrasting the types of women present in the Nobel prize winner's work with Metta Trap, she came to the conclusion that they represent two extremities; the author of Kristin Lavransdatter describes a woman of the past, while Michaëlis constructs the future with a "new type of a woman, not the one who's fighting and falling under the prejudice and public opinion, but the modern one, creating new life and new laws in the name of her own happiness".

The author of the preface chosen by the publishing house should also be mentioned. In 1929 Maria Kuncewiczowa took part in a literary scandal: her novel, Przymierze $z$ dzieckiem, published two years prior, undermined the established conviction that women have an inherent maternal instinct, portraying the gradual development of love for a child initially perceived as a monster. It was also her works that were the subject of one of the most important literary controversies of the interwar period, that is the debate about women's literature, initiated by Irena Krzywicka. The publicist working with "Wiadomości Literackie" strongly opposed the excessively metaphorical, elevated style, the artificially exuberant emotionality and extensive descriptions masking the lack of content or even intellectual laziness, complaining also of the "flashiness" and "obliviousness" distinctive for women's writing. The "feminine tattle" characteristic of some of the postwar prose, that is the simpering, hysterically exaggerated language, was for her an anachronism, the legacy of the Young Poland period, typical for "weepy, simpering little girls", not 
adequate for modern women, who should be "reasonable, brave and conquering". Although Kuncewiczowa's name was never mentioned, Krzywicka quoted and crudely commented on fragments of her works ${ }^{12}$. The author decided to answer the criticism, agreeing with Krzywicka's claim about the differences between men and women writing, but unlike her colleague valuing them and urging to respect diversity.

Krzywicka's Jazgot niewieści, albo przerost stylu was published in issue 42 from 14 October 1928 of "Wiadomości Literackie". In the following weeks, almost until the end of the year, the periodical was the battleground of the debate, with subsequent comments from Krzywicka and Kuncewiczowa, and also from male literary critics, Antoni Słonimski, Paweł Hulka-Laskowski and Karol Irzykowski, who mainly agreed with Krzywicka. It is not the place to reconstruct the specific standpoints (Krajewska, 2010), however it is important to draw attention to the fact, that when Kuncewiczowa was writing the preface to The Dangerous Age, in print dated for 14 XII 1928, she was under the direct influence of this debate, and it had to had an affect on the manner in which she wrote it. This explains the surprising tone of her words, for she starts by admitting, that "The Dangerous age is still a new work. Full of revelations. Full of uncomfortable truths", and then mentions the changes in defining the nature of a woman and a man, occurring before her eyes. The former, due to economic independence, becomes more similar to a man, who, in contrast, adopting pacifist ideology and the like, loses his masculinity and gains feminine features. In the face of those transformations, discussing Michaëlis's works may seem irrelevant ("The inner struggle of Elsie Lindtner - the tragic 40-year old - connected with her complete idleness is hard to grasp for the modern overworked, active woman"). However, it is an illusion. The protagonist may be a remnant of the past, but according to Kuncewiczowa the author's insights into the physiology and psychology of aging remain a revelation. The preface ends with

12 Accusations made against Kuncewiczowa were repeated by Krzywicka about Michaëlis herself. In her review of Pan i dziewczyna in 1931 in "Wiadomości Literackie" she wrote: "Karin Michaëlis's views are correct, but she is not talented. To be perfectly honest, I could not read any of her books to the end, I skimmed through them, one large volume an hour. Her novels are so full of water, that one should have a special ladle to extract some valuable and wise thoughts. An intelligent reader, tired of wading knee-deep in artistic flatness and vexed by the hysterical style, will obviously capitulate" (Krzywicka, 1931: 3). Michaëlis was also compared to Kuncewiczowa by Bruno Schulz. When in 1937 he reviewed the Polish edition of the autobiographical Serce mojej matki (orig. Mor), he compared it to Cudzoziemka, published the previous year. The critic, fascinated with psychoanalysis, claimed that both novels are "an attempt at releasing the mother complex, a reckoning with the deceased mother, and a sort of expiation, overcoming the complex through artistic objectivization" (Schulz, 1937: 3). 
a surprising conclusion: "Closing the book we think: this is how females suffer and pass away - but women live forever” (Kuncewiczowa, 1929: 5-8).

\section{A hundred years later}

After the peak of Michaëlis's popularity in the late 1920s, her career in Poland and elsewhere gradually waned. In 1932 Polish women's press did mention the writer's 60th birthday, but rather as a farewell. Aniela Waldenbergowa's article published in "Bluszcz" is openly a nostalgic reminiscence. The Polish translator of Metta Trap, Siedem sióstr, Sznur peret, all parts of Gunhilda and the series about Bibi admits that when The Dangerous Age was published in 1910, she did not enjoy it. She was a young girl who could not understand the psychology of the protagonist or feel compassionate toward her: "the book, read only once, lay forgotten in the corner of the library". She was impressed, however, with Michaëlis's postwar works. After reading Metta Trap, she asked the publisher for permission to translate it. Not long after, with a "pounding heart", she welcomed the Dane in Warsaw. The ladies became close friends, and during her second visit in Warsaw the writer stayed with Waldenbergowa. The translator was ill at the time, and the guest took care of her and her son, taking him to the cinema and saving him from learning mathematics. Waldenbergowa thought of the intimate moments spent with the famous author as ones of the best in her life (Waldenbergowa, 1932: 7-8).

In "Kurier Kobiecy", another young author, Jolanta Fuchsówna, wrote about Michaëlis's jubilee (Fuchsówna, 1932: 18). The journalist, who was only 11 when The Dangerous Age was published, based her article on the simple claim, that the writer, crossing her sixtieth year in the peak of her creative abilities, proved that the female dangerous age did not exist anymore. The author, expressing her appreciation for the revolutionary character of Michaëlis's famous novel, emphasized several times that it was twenty years ago. For her generation, the work was already historical and outdated, useful only as a reminder of the scale of social change the women had won.

In the 1930s, Michaëlis, mentioned from time to time as the pioneer of the women's emancipation movement, functioned on the Polish market mainly as a children's author. In 1918 her Radosna szkota was translated into Polish as a book for the child audience. It was never mentioned by the editor, that through the character of Ludwika the author depicted her friend, Eugenia Schwarzwald, a propagator of anti-authoritarian teaching, who established an experimental school for girls in 
Vienna. In the introduction to Radosna szkota, Michaëlis included the answer to the question of why she wrote a book in no way connected to her earlier writings. She explained that while writing about adult women, she always described their youth, convinced, that "all of the thought and feeling of an adult, particularly a woman, begins in childhood" (Michaëlis, 1918). Indeed, this issue is explored further in the semi-autobiographical series Traet paa godt og ondt $t^{13}$, however the series Bibi was simply a collection of stories for children ${ }^{14}$. Likewise, Dzieci z Nyhavn, first published in Polish in 1938 was also aimed at children. It is the only book of the Danish author which was reprinted in Poland after World War II, in 1947, 1948 and 1955. The already-mentioned jubilee article by Waldenbergowa ended in fact with Michaëlis receiving hundreds of letters from children a day, and admitting: "I do not regret not having a child of my own. I would drown in love for him, and I love all children so much". It truly is an unexpected ending to the former scandalist's career. Surprisingly, other feminist bestsellers mentioned in the introduction met similar fate. The novels of Brontë and Stowe quickly became children's literature as well. A proof can be find in the second Polish edition of Radosna szkota, where the advertisements of different works recommended to children include Uncle Tom's cabin and a paraphrase of Jane Eyre entitled Sierota $z$ Lowood, presented with words: "the amiable author outlines the fate of a young heart, blooming to be ready for love among conflicts full of dramatic suspense".

According to Merete von Eyben, Michaëlis's fortune is an example of the "Jante law" (Janteloven), which claims that the Danish people banish the fellow countrymen who achieved success outside of the country. Indeed, not only in Poland prewar translations of her works were not reprinted and new ones were not created. The writer was shortly forgotten even in her homeland, Denmark. Due to her political commitment (after the Nazis rose to power, she gave shelter to German and Austrian refugees, among others to Bertolt Brecht and Walter Benajmin [Hollander, 2016: 123-141]) she spent World War II on immigration in the USA, where her shortlived success was not remembered. Otherwise, she was cut off from the profit from her books sold in Europe, which at the time were banned both in Germany and in occupied Denmark. When in 1946 she returned to her homeland, it became

13 Three of the total five parts were published in Poland between 1929 and 1932, that is Gunhild, Pierwsza mitość Gunhildy and Tajemnica; the third volume, Grzechy, troski i niebezpieczeństwa could not be found, most probably it was never issued.

14 Two of the six parts were published in Poland, both translated by Aniela Waldenbergowa (Michaëlis, 1932, second edition 1933; Michaëlis, 1937). 
evident that Danish readers forgotten her as well. To make a living, she had to sell her property on the Thurø island, and she lived in near poverty until the end of her life. The first postwar edition of The Dangerous Age was published in the USA, as late as 1991, and even then was not noticed.

\section{Works cited}

"All heroines not youthful. Karin Michaëlis, the Literary Sensation of Europe". New York Times July 30 (1911).

Chwastyk-Kowalczyk, Jolanta. "Bluszcz" w latach 1918-1939: tematyka spoteczna oraz problemy kultury i literatury. Kielce: Wydawnictwo Akademii Świętokrzyskiej, 2003.

[Dąbrowska, Maria] m.s.d. "Z książek”. Kobieta Wspótczesna 10 (1927): 16.

"Echa Prawdy". Prawda 13 (1911): 8.

Eddy, Beverly D. "The Dangerous Age: Karin Michaëlis and the Politics of Menopause". Women's Studies 21 (1992): 491-504.

----. Karin Michaëlis: Kaleidoskop des Herzens. Eine Biographie. Übers. von Vibeke Munk, Jörg Zeller. Wien: Edition Praesens, 2003.

----. Hjertets kalejdoskop: En biografi om Karin Michaëlis. Revideret og oversat af Kirsten Klitgård. København: Karin Michaëlis Selskabet, 2013.

Eyben von, Merete. Karin Michaëlis: Incest as Metaphor and the Illusion of Romantic Love. New York: Peter Lang, 2003.

Fuchsówna, Jola. "Karin Michaëlis i «niebezpieczny wiek»". Kurier Kobiecy 13 (1932): 18.

Hollander, Katherine. "Bridges and Islands: Community and Karin Michaëlis in and out of Exile, 1907-1942”. Networks of Refugees from Nazi Germany, Continuities, reorientations, and collaborations in Exile. Ed. Helga Schreckenberger. Boston: Brill, 2016. 123-141.

Iwieński, Alfred. "Komentarz tłumacza". In: Michaëlis, Karin. Wiek niebezpieczny. Trans. by A. Iwieński. Warszawa: Ultima Thule, 1911. 177-182.

Kallas, Aniela. "Karin Michaëlis”. Wiek Nowy 7727 (1927): 10-11.

Kaluta, Izabella. "Róża i Barbara”. Teksty Drugie 3-4 (1995): 158-173.

"Karin Michaëlis's The Dangerous Age in the Light of Psychoanalysis. T. Rosenthal" [abstract]. The Psychoanalytic Review 4 (1917): 341.

"Karin Michaëlis w oświetleniu krakowskiego krytyka". Eódzkie Echo Wieczorne 72 (1927): 2.

Klemensiewiczowa, Józefa. “Karin Michaëlis”. Prawda 18 (1905): 213-214. 
Kłosińska, Krystyna. Ciato, pożądanie, ubranie. O wczesnych powieściach Gabrieli Zapolskiej. Kraków: Wydawnictwo eFKa, 1999.

Krajewska, Joanna. „Jazgot niewieści” i „męskie kasztele”. $Z$ dziejów sporu o literaturę kobieca w Dwudziestoleciu Międzywojennym. Poznań: Wydawnictwo Poznańskiego Towarzystwa Przyjaciół Nauk, 2010.

Krawczyńska, Jadwiga. "Z fali dnia: orędowniczka kobiet”. Kobieta Wspótczesna 2 (1927): 14-15.

Krzywicka, Irena. “O Karin Michaëlis”. Wiadomości Literackie 33 (1931): 3.

Kuncewiczowa, Maria. "Wstęp”. Michaëlis, Karin. Niebezpieczny wiek. Notatki z pamiętnika i listy. Trans. by Bronisława Neufeldówna. Warszawa: Rój, 1929. 5-8.

Lassner, Phyllis. "Foreword". Michaëlis, Karin. The Dangerous Age. Letters and Fragments from a Woman's Diary. Evaston Illionois: Nortwestern University Press, 1991. 1-24.

Ligensa, Annemone. " "A Cinematograph of Feminine Thought»: The Dangerous Age, Cinema and Modern Women”. Film 1900: Technology, Perception, Culture. Eds. Annemone Ligensa, Klaus Kreimeier. Bloomington: Indiana University Press, 2015. 225-237.

“Literatura i sztuka u obcych. Nowości literackie”. Nowa Gazeta 11 (1911): 7.

Michaëlis, Karin. Wstepie. Powieść. Trans. by A.B. [Aleksander Birkenmajer]. Warszawa: Piotr Laskauer, 1904.

---. Losy Ulli Fangel. Dzieje mtodości i matżeństwa. Trans. by Edgar Schnell. BrodyWarszawa: F. West, 1905.

---. “Duszyczka”. Trans. by Józefa Klemensiewiczowa. Prawda 30-35 (1907).

----. Beata Rosa. Trans. by. E. R-a [Emilia Rabicka]. Warszawa: E. Nicz, 1911 a.

----. Niebezpieczny wiek. Pamiętnik i listy. Trans. by Kazimierz Króliński. Lwów: Kultura i Sztuka, 1911b.

----. Wiek niebezpieczny. Trans. by Alfred Iwieński. Warszawa: Ultima Thule, 1911c.

----. Niebezpieczny wiek kobiety. Trans. by Aleksandra Callier. Warszawa-Kraków: Gebethner i Wolff, 1911d.

----. Radosna szkota. Trans. by Aniela Kallas. Lwów: Kultura i sztuka, 1918; second edition 1922.

----. Pani Jonna. Trans. by Bronisława Neufeldówna. Warszawa: Rój, 1927a.

----. Metta Trap. Trans. by Aniela Waldenbergowa. Warszawa: Rój, 1927b.

----. Bibi. Życiorys matej dziewczynki. Trans. by Aniela Waldenbergowa. Warszawa: Rój, 1932; second edition 1933.

----. Bibi podróżuje. Trans. by Aniela Waldenbergowa. Warszawa: Nasza Księgarnia, 1937.

----. Dzieci z Nyhavn. Trans. by Tadeusz Zabłudowski. Warszawa: Księgarnia Popularna, 1938. 
Miszewska, Zofia. "Od bieguna do bieguna“. Bluszcz 8 (1929): 6-7.

Mucha, Ignacy. "Krytyka”. Prawda 13 (1911): 7-8.

[Naglerowa, Herminia] J-a. Stycz. "Programowość Karin Michaëlis”. Bluszcz 15 (1927): $2-3$.

Nałkowska, Zofia. “O Karin Michaëlis”. Wiadomości Literackie 28 (1927): 1.

Nałkowska, Zofia. Dzienniki 1909-1917. Ed. Hanna Kirchner. Warszawa: Czytelnik, 1976.

Nałkowska, Zofia. Dzienniki 1918-1929. Ed. Hanna Kirchner. Warszawa: Czytelnik, 1980.

“Niebezpieczny wiek u kobiet”. Nowa Reforma 26 (1911): 2.

[Obituary for Aleksandra Callier]. Ilustrowany Kurier Codzienny 204 (1923): 3.

Okołów-Podhorska, Stefania. "Rozmowa z Karin Michaëlis”. Bluszcz 15 (1927): 1-2.

Розенталь, Т.К. “«Опасный возраст» в свете психоанализа”. Психотерапия (1911): 189-194, 273-289.

Rosenthal, Tatiana. “"Das gefährliche Alter» im Lichte der Psychoanalyse”. Zentralblatt für Psychoanalyse 7/8 (1911): 277-294.

Schulz, Bruno. "U wspólnej mety: Maria Kuncewiczowa i Karin Michaëlis”. Pion 35 (1937): 3 .

Showalter, Elaine. A jury of her peers. American women writers from Anne Bradstreet to Annie Proulx. London: Virago, 2010.

Sowiński, Janusz. "Stylizacja typograficzna druków Wydawnictwa Ultima Thule (1910-1939)”. Sztuka ksiązki. Historia - teoria-praktyka. Ed. Małgorzata Komza. Wrocław: Wydawnictwo Uniwersytetu Wrocławskiego, 2003. 91-107.

Spychalska-Wilczurowa, Grażyna. "Stanisław Franciszek Michalski”. Przegląd Orientalistyczny 2 (1962): 129-133.

Stewart, Janet. Public Speaking in the City: Debating and Shaping the Urban Experience. Basingstoke: Palgrave Macmillan 2009.

Szpakowska, Małgorzata. "Wiadomości Literackie” prawie dla wszystkich. Warszawa: W.A.B., 2012.

Świdziński, Wojciech. Co byto grane? Film zagraniczny w Polsce w latach 1918-1929 na przyktadzie Warszawy. Warszawa: Instytut Sztuki PAN, 2015.

Waldenbergowa, Aniela. "Karin Michaëlis”. Bluszcz 14 (1932): 7-8.

"Wiek niebezpieczny". Nowa Gazeta 44 (1911): 4.

Zawiszewska, Agata. Między Mtodą Polską, Skamandrem i awangarda. Kobiety piszące wiersze $w$ dwudziestoleciu międzywojennym. Szczecin: Wydawnictwo Naukowe Uniwersytetu Szczecińskiego, 2014. 


\title{
The Dangerous Age: Polish Reception of Karin Michaëlis's Feminist Bestseller
}

\begin{abstract}
Summary
The article presents the novel Den farlige Alder (1910) by a forsaken Danish woman writer, Karin Michaëlis. Its worldwide popularity was unprecedented and made its author in no time into a star. Her odd career, from literary scandalist to bland children's author, lasted almost 20 years. After the World War II her works ceased to be reprinted and she was shortly forgotten even in Denmark. By pointing out the most important stages of The Dangerous Ages's reception in Poland, the article proposes to ponder over the mechanisms behind the making of feminist bestsellers.
\end{abstract}

Keywords: Karin Michaëlis, Den farlige Alder (The Dangerous Age, Wiek niebezpieczny), feminist bestsellers, women writers

Słowa kluczowe: Karin Michaëlis, Den farlige Alder (The Dangerous Age, Wiek niebezpieczny), feministyczne bestsellery, kobiety pisarki 